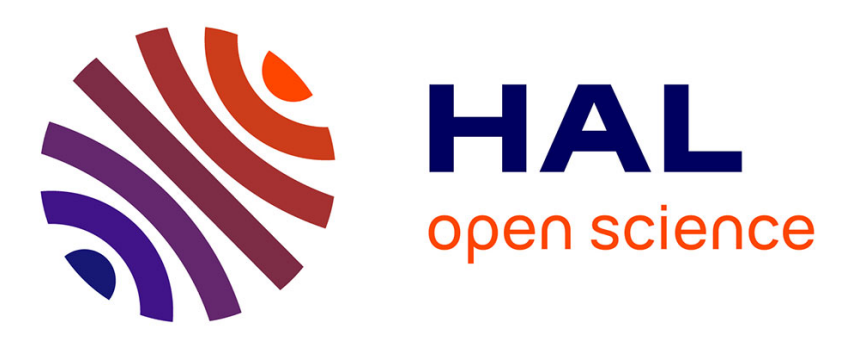

\title{
Ethnobiology Phase VI: Decolonizing Institutions, Projects, and Scholarship
}

Alex C Mcalvay, Chelsey G Armstrong, Janelle Baker, Linda Black Elk, Samantha Bosco, Natalia Hanazaki, Leigh Joseph, Tania Eulalia Martínez-Cruz, Mark Nesbitt, Meredith Alberta Palmer, et al.

\section{To cite this version:}

Alex C Mcalvay, Chelsey G Armstrong, Janelle Baker, Linda Black Elk, Samantha Bosco, et al.. Ethnobiology Phase VI: Decolonizing Institutions, Projects, and Scholarship. Journal of Ethnobiology, 2021, 41 (2), pp.170-191. 10.2993/0278-0771-41.2.170 . hal-03281929

\section{HAL Id: hal-03281929 https://hal.science/hal-03281929}

Submitted on 8 Jul 2021

HAL is a multi-disciplinary open access archive for the deposit and dissemination of scientific research documents, whether they are published or not. The documents may come from teaching and research institutions in France or abroad, or from public or private research centers.
L'archive ouverte pluridisciplinaire HAL, est destinée au dépôt et à la diffusion de documents scientifiques de niveau recherche, publiés ou non, émanant des établissements d'enseignement et de recherche français ou étrangers, des laboratoires publics ou privés. 


\section{BioOne COMPLETE}

\section{Ethnobiology Phase Vl: Decolonizing Institutions, Projects, and Scholarship}

Authors: McAlvay, Alex C., Armstrong, Chelsey G., Baker, Janelle, Elk, Linda Black, Bosco, Samantha, et al.

Source: Journal of Ethnobiology, 41(2) : 170-191

Published By: Society of Ethnobiology

URL: https://doi.org/10.2993/0278-0771-41.2.170

BioOne Complete (complete.BioOne.org) is a full-text database of 200 subscribed and open-access titles in the biological, ecological, and environmental sciences published by nonprofit societies, associations, museums, institutions, and presses.

Your use of this PDF, the BioOne Complete website, and all posted and associated content indicates your acceptance of BioOne's Terms of Use, available at www.bioone.org/terms-of-use.

Usage of BioOne Complete content is strictly limited to personal, educational, and non - commercial use. Commercial inquiries or rights and permissions requests should be directed to the individual publisher as copyright holder.

BioOne sees sustainable scholarly publishing as an inherently collaborative enterprise connecting authors, nonprofit publishers, academic institutions, research libraries, and research funders in the common goal of maximizing access to critical research. 


\title{
Ethnobiology Phase VI: Decolonizing Institutions, Projects, and Scholarship
}

\author{
Alex C. McAlvay ${ }^{1 *}$, Chelsey G. Armstrong², Janelle Baker ${ }^{3}$, Linda Black \\ Elk $^{4}$, Samantha Bosco ${ }^{5}$, Natalia Hanazaki ${ }^{6}$, Leigh Joseph ${ }^{7}$, Tania Eulalia \\ Martínez-Cruz ${ }^{8}$, Mark Nesbitt ${ }^{9}$, Meredith Alberta Palmer ${ }^{10}$, Walderes \\ Cocta Priprá de Almeida ${ }^{11}$, Jane Anderson ${ }^{12}$, Zemede Asfaw ${ }^{13}$, Israel \\ T. Borokini ${ }^{14}$, Eréndira Juanita Cano-Contreras ${ }^{15}$, Simon Hoyte ${ }^{16}$, Maui \\ Hudson ${ }^{17}$, Ana H. Ladio ${ }^{18}$, Guillaume Odonne ${ }^{19}$, Sonia Peter ${ }^{20}$, John \\ Rashford $^{21}$, Jeffrey Wall ${ }^{22}$, Steve Wolverton ${ }^{23}$, and Ina Vandebroek ${ }^{1}$
}

\begin{abstract}
Ethnobiology, like many fields, was shaped by early Western imperial efforts to colonize people and lands around the world and extract natural resources. Those legacies and practices persist today and continue to influence the institutions ethnobiologists are a part of, how they carry out research, and their personal beliefs and actions. Various authors have previously outlined five overlapping "phases" of ethnobiology. Here, we argue that ethnobiology should move toward a sixth phase in which scholars and practitioners must actively challenge colonialism, racism, and oppressive structures embedded within their institutions, projects, and themselves. As an international group of ethnobiologists and scholars from allied fields, we identified key topics and priorities at three levels: at the institutional scale, we argue for repatriation/rematriation of biocultural heritage, accessibility of published work, and realignment of priorities to support community-driven research. At the level of projects, we emphasize the need for mutual dialogue, reciprocity, community research self-sufficiency, and research questions that support sovereignty of Indigenous Peoples and Local Communities over lands and waters. Finally, for individual scholars, we support self-reflection on language use, co-authorship, and implicit bias. We advocate for concrete actions at each of these levels to move the field further toward social justice, antiracism, and decolonization.
\end{abstract}

Keywords: ethics, social justice, antiracism, colonialism, parachute science

${ }^{1}$ Institute of Economic Botany, The New York Botanical Garden, 2900 Southern Blvd, Bronx, NY 10458.

${ }^{2}$ Indigenous Studies, Simon Fraser University, Burnaby, BC, Canada.

${ }^{3}$ Anthropology, Athabasca University, Athabasca, Alberta, Canada.

${ }^{4}$ United Tribes Technical College, Bismarck, North Dakota.

${ }^{5}$ Horticulture Section, School of Integrated Plant Sciences, Cornell University, Ithaca, New York.

${ }^{6}$ Departamento de Ecologia e Zoologia, Universidade Federal de Santa Catarina, Florianópolis, Brazil.

${ }^{7}$ School of Environmental Studies, University of Victoria, BC, Canada.

${ }^{8}$ Natural Resources Institute, University of Greenwich, Chatham, United Kingdom.

${ }^{9}$ Royal Botanic Gardens, Kew, Richmond, Surrey, UK.

${ }^{10}$ Science and Technology Studies Department, American Indian and Indigenous Studies Program, Cornell University, Ithaca, New York.

${ }^{11}$ Departamento de História, Universidade Federal de Santa Catarina, Florianópolis, Brazil.

${ }^{12}$ Equity for Indigenous Research and Innovation Coordinating Hub, Anthropology and Museum Studies, New York University, New York, New York.

${ }^{13}$ Department of Plant Biology and Biodiversity Management, Addis Ababa University, Addis Ababa, Ethiopia.

${ }^{14}$ Ecology, Evolution and Conservation Biology Graduate Program, Department of Biology, University of Nevada, Reno, Nevada.

${ }^{15}$ Centro de Investigaciones Multidisciplinarias sobre Chiapas y la Frontera Sur, Universidad Nacional Autónoma de México, Chiapas, México.

${ }^{16}$ Department of Anthropology, University College London, London, United Kingdom.

${ }^{17}$ Te Kotahi Research Institute, University of Waikato, Hamilton, New Zealand.

${ }^{18}$ INIBIOMA (CONICET-Universidad Nacional del Comahue), San Carlos de Bariloche, Río Negro, Argentina.

${ }^{18}$ CNRS-LEEISA (USR 3456), Cayenne, French Guiana.

${ }^{20}$ Biocultural Education and Research Programme, St. James, Barbados.

${ }^{21}$ Department of Sociology and Anthropology, College of Charleston, Charleston, South Carolina.

${ }^{22}$ Department of Geography, Environment and Geomatics, University of Guelph, Ontario, Canada.

${ }^{23}$ Department of Geography and the Environment, University of North Texas, Denton, Texas.

*Corresponding author (amcalvay@nybg.org) 
Resumen. La etnobiología, como muchos otros campos, ha sido moldeada por los esfuerzos imperialistas occidentales para colonizar gente y tierras alrededor del mundo y extraer sus recursos naturales. Estos legados y prácticas aún persisten hoy en día y continúan influyendo en las instituciones donde los etnobiólogos son parte, las formas en cómo desarrollan la investigación, sus creencias personales y acciones. Varios autores han resaltado anteriormente cinco fases superpuestas de la etnobiología. En este documento, nosotros argumentamos que la etnobiología debe moverse hacia una sexta fase en la que los académicos y practicantes deben activamente confrontar el colonialismo, el racismo y las estructuras opresivas que están embebidas dentro de sus instituciones, proyectos y de ellos mismos. Como un grupo internacional de etnobiólogos y académicos de campos aliados, identificamos temas centrales y prioridades en 3 niveles: a nivel institucional, nosotros abogamos por la repatriación/rematriación del patrimonio biocultural, la accesibilidad a los trabajos publicados, y la realineación de prioridades para apoyar la investigación liderada por las comunidades. A nivel de proyectos, nosotros enfatizamos la necesidad de un diálogo mutuo, de reciprocidad, que las comunidades sean autosuficientes en cuanto a investigación. Además, que las preguntas de investigación apoyen la soberanía de los Pueblos Indígenas y las Comunidades Locales sobre sus tierras y aguas. Finalmente, en el caso de los académicos, apoyamos los procesos de reflexión interna acerca del uso del lenguaje, las coautorías y los sesgos implícitos. Nosotros abogamos por acciones concretas en cada uno de estos niveles para movilizar a la etnobiología para que sea socialmente justa, anti-racista y descolonizada.

\section{Palabras clave: Ética, Justicia Social, Antiracismo, Colonialismo, Ciencia Paracaídas}

Introdução. A etnobiologia foi moldada, como muitas áreas de estudo, por anseios imperialistas do Ocidente para extrair recursos naturais e colonizar terras e povos ao redor do mundo. O legado destas práticas persiste até hoje e continua a influenciar as instituições que etnobiólogos fazem parte, como eles fazem suas pesquisas, e suas ações e crenças pessoais. Muitos autores já delinearam cinco fases na Etnobiologia que se sobrepõem. Aqui, nós argumentamos que a Etnobiologia deve de se mover para uma sexta fase, onde acadêmicos e praticantes deveriam desafiar ativamente as estruturas opressoras de racismo e colonialismo que são tão presentes em suas instituições e em seus próprios projetos e em si mesmos. Como um grupo internacional de etnobiólogos e acadêmicos de áreas em comum, nós identificamos tópicos essenciais em três níveis de prioridade: numa escala institucional, nós prezamos por uma repatriação/rematriação de patrimônio biocultural, acessibilidade de trabalhos publicados e um realinhamento de prioridades para auxiliar pesquisas direcionadas pelas comunidades. No nível de projetos, enfatizamos a necessidade do diálogo mútuo, reciprocidade, à auto suficiência de pesquisas comunitárias, e questões de pesquisa que apoiam Povos Indígenas e comunidades locais e sua soberania sobre suas terras e águas. Para o nível acadêmico individual, nós apoiamos a autorreflexão no uso da linguagem, co-autoria, e vieses implícitos. Nós defendemos ações concretas em cada um destes níveis para impulsionar cada vez mais o campo de estudo na direção da justiça social, anti racismo e descolonização.

Palavras-chave: Ética, Justiça social, Antiracismo, Colonianlismo, Ciência paraquedas

\section{Dén lálá to togtũ to pil: Dén ve to vãnhlán lálá dén to vãnhlá la}

Dén pledeg jé ke te kũ tõ ũn pil han kũ, te u ve tẽ kũ to mẽ ag bag gó tẽ tẽ génh kan mũ. Dén mẽ plẽdeg ge tẽ tõ vel há tẽg te kũ, pa'i tõ to nõdẽg te óg ẽ jogzẽ tẽ ha lan lán gé ke mũ. Ũ tõ dén to mẽ vanhlán lán gé ké mũ te óg ẽ vanh lá lá tẽ tõ hun ge mũ. Tóg tẽ ki, ag ha na dén plẽdeg ke te zé txul kũ vãtxika zé ke vã, kũ vaha ũ tõ dén zópalag nõ óg ha vũ to nõdẽ kũ to vẽ ke tẽ tẽ like ti, jé ũ tõ mẽ ãggónhka óg kulégvég gé ke mũ te óg, vel to nõ ũ ha tã paí nõdẽ kũ ẽ han dén ti zé vanhlán lán gé ke mũ. Ag mõ gojvanh mẽ nõ óg vãtxo vagzun kũ zé zópalag nõdẽ, u ta tẽ ag mõ like te jé je ta ag pate tég: Vel ag ha na dén u tẽ ze txul kũ tõ lẽl tẽ tõ ag tẽ te kũ, zé lanhlanh ke te jé u tég like te jé ha ve kũ ha to dén tẽ han ge tẽ aglẽl te óg mõ. Vanhlán lálá te to mẽ óg blé vẽ kũ óg ve kũ han ge tẽ, kũ vel jé ta u tég kũ a ve kũ ha to un pã han ge tẽ aglẽl te óg mõ, jé ta ãggónhka te óg mõ vel tég óg ka te mẽ óg goj te blé. Vel ẽ tõ dén zópalag nõdẽ te óg mõ vãnhku tẽ ké, ag mõ ta u tẽ te lán lálá tẽ, kũ vãnhõ blé dén han ge jé ta tég, dén jógdẽg to akleg mãka. Dén u zé aklén kũ to zópzlag ge jé ta tég. 


\section{Introduction}

In this paper, we make a call for an ethnobiology centered on anti-oppressive activism that addresses colonial legacies and ongoing colonialism. We recognize that hundreds of years of colonial policies and practices have contributed, and continue to contribute, to poverty, exclusion, state violence, sexism, classism, and racism in many contemporary societies. They additionally continue to shape academic institutions, research projects, and individual beliefs and actions.

Over time, ethnobiology as a scientific discipline has taken major turns that have been conceptualized as phases (see Table 1) (Clément 1998; Hunn 2007; Nabhan et al. 2011; Wolverton 2013; Wyndham et al. 2011). Rather than mutually exclusive categories or an evolutionary trajectory, these phases highlight major trends and emerging lines of inquiry in the field. In introducing Phase 1, Clément (1998) explains that while humans have engaged in ethnobiological research for thousands of years, contemporary academic ethnobiology has its roots in late nineteenth century European and Eurodescendant researchers' efforts to "discover" new uses for plants that can benefit settlers and/or colonial powers. This interest in ethnobiology was global. That is, by 1914, the majority of the world's countries had been colonized by Europeans (Ferrante 2014) and, since the fifteenth century "Age of Discovery," newly encountered spices, seeds, tea, furs, and other goods were being funneled toward European powers.

In the twentieth century, additional trends emerged with a focus on local taxonomic systems (Phase II) and traditional ecological knowledge (Phase III). The late twentieth and early twenty-first centuries saw increasing attention to ethnobiologists' responsibilities to the communities they work with (Phase IV) and growing application of ethnobiology to global environmental challenges (Phase V) (Nabhan et al. 2011; Wolverton 2013; Wyndham et al. 2011). Ethnobiologists continue to carry out

Table 1. Five phases of ethnobiology proposed by Clément (1998), Hunn (2007), Wyndham et al. (2011), Nabhan et al. (2011), and Wolverton (2013).

\begin{tabular}{|c|c|}
\hline Phase & Hallmarks \\
\hline I. Utilitarianism & $\begin{array}{l}\text { Documentation of plant and animal uses that could benefit the } \\
\text { researcher's society (e.g., Heinrich and Bremner 2006) }\end{array}$ \\
\hline II. Cognitive Ethnobiology & $\begin{array}{l}\text { Linguistics and psychology incorporated to study how cultures } \\
\text { conceive of and classify organisms in the environment (e.g., } \\
\text { Berlin 1992; Conklin 1954) }\end{array}$ \\
\hline III. Ethnoecology & $\begin{array}{l}\text { Traditional ecological knowledge and its application } \\
\text { increasingly emphasized (e.g., Berkes 2012; Toledo and } \\
\text { Alarcón-Cháires 2018) }\end{array}$ \\
\hline IV. Indigenous Ethnobiology & $\begin{array}{l}\text { Increasing awareness of the importance of rights of Indigenous } \\
\text { peoples to control how their knowledge is extracted, shared, or } \\
\text { used (e.g., Golan et al. 2019; Posey 1990) }\end{array}$ \\
\hline $\begin{array}{l}\text { V. Interdisciplinarity in an Era of Rapid } \\
\text { Environmental Change }\end{array}$ & $\begin{array}{l}\text { Emphasizes interdisciplinary collaboration to address pressing } \\
\text { human-environmental issues such as climate change (e.g., } \\
\text { Reyes-García et al. 2019; Salick et al. 2009) }\end{array}$ \\
\hline
\end{tabular}


work oriented toward all the above phases and usually blend them together.

We call for a Phase VI to address colonial legacies in the field and ongoing colonialism globally. Guided by turns in other disciplines, we argue that ethnobiologists' work needs to go beyond adhering to and satisfying ethical guidelines and be actively decolonizing (Atalay 2012; Baker et al. 2019; Harrison 2010; Radcliffe 2017; Smith 2012). Here, we define colonialism broadly as "the control by individuals or groups over the territory and/or behavior of other individuals and groups" (Horvath 1972:46). The contexts of colonization vary dramatically between and within countries, including "settler colonialism," where settlers claim land and become the majority, "extractive colonialism," which involves exploitation of local resources but does not entail permanent occupation, and any combination of other forms (Shoemaker 2015). Many scholars also note that, even in "decolonized" countries, colonial dynamics can persist through "neocolonialism" in the form of economic exploitation and political manipulation (Rahaman et al. 2017), as well as internal structures set up by colonialism related to power, wealth, race, and class (Maitra and Guo 2019). We argue that concrete steps should be taken to "decolonize" the discipline of ethnobiology in two senses of the word: 1) by remedying lingering colonial legacies embedded within institutions, research projects, and scholars, and 2) by actively opposing ongoing colonialism by supporting sovereignty over land, waters, and biocultural heritage by Indigenous Peoples and Local Communities.

As in Phases I-V, which overlap and interact with one another, we believe that there is potential synergy between Phase $\mathrm{VI}$ and other phases. For example, Phase VI, like II (cognitive ethnobiology) and III (ethnoecology), valorizes local perspectives of the natural world and Phase IV (Indigenous ethnobiology) overlaps with our call to reexamine relationships with the communi- ties ethnobiologists work with. Additionally, an actively anti-oppressive ethnobiology VI may improve ethnobiologists' ability to address the global challenges of Phase $\mathrm{V}$, such as environmental justice.

In this paper, we organized our thinking across three overlapping scales: institutions, projects, and scholars (Figure 1). Inspired by the teachings of historian and antiracist activist Ibram X. Kendi (2017), we started from institutions, policies, and structures, which Kendi argues are at the root of inequity and, in turn, influence our actions and ideas. Next, the two coordinating authors (McAlvay and Vandebroek) contacted other colleagues who, in three sub-groups, jointly reflected on and wrote about decolonizing ethnobiology at these thematic scales. This larger author network invited other authors from around the world based on previously expressed interest, professional experience, or their answers to a few questions circulated by the coordinating authors online about decolonizing ethnobiology. The final group of 24 authors brings together ethnobiologists, conservation specialists, and geographers based at universities and non-profits in 10 countries. The authors include Indigenous and non-Indigenous scholars, but nearly all contributors work closely with Indigenous Peoples and Local Communities. We consciously worked to minimize discipline-specific jargon to be inclusive of a diverse readership.

We recognize that communities worldwide have been affected by colonialism, including many who do not identify as Indigenous. In general, the analysis and recommendations in this paper refer to all those who face structural disadvantage as a result of historic and present-day colonialism, including Indigenous Peoples and Local Communities in many parts of the world and descendants of enslaved or indentured peoples. Continued reflection on issues of inclusion resulting from the use of "local" is crucial, so as not to exclude, for example, Afrodescendant communities 


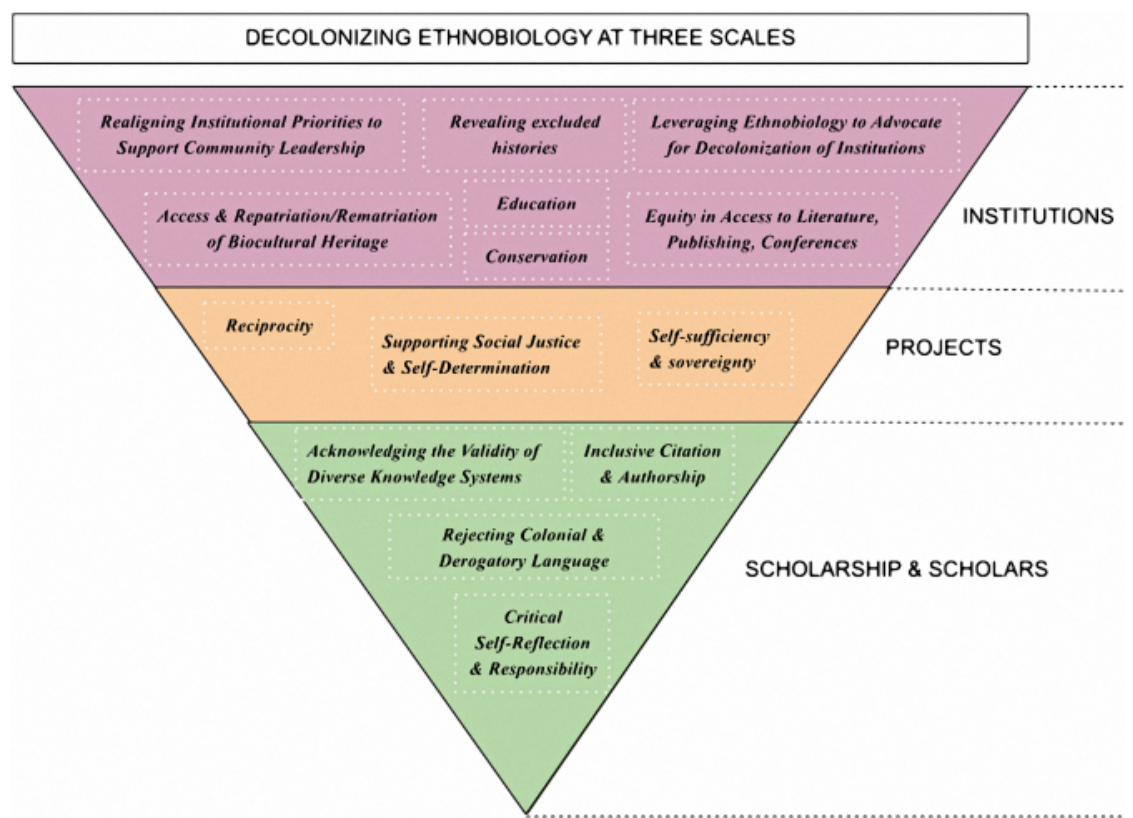

Figure 1. Key topics and priorities for decolonizing ethnobiology at the three thematic scales discussed in this paper, narrowing from institutions to projects and scholarship.

historically displaced from their ancestral lands from dialogue on traditional knowledge systems defined by long histories of interactions between peoples and their natural surroundings. We also emphasize that ethnobiologists frequently work in their own communities; there is not necessarily a distinction between "researchers" and othered "community members."

\section{Decolonizing Institutions}

Ethnobiology is embedded in a variety of institutions, including universities, museums, botanical gardens, non-governmental organizations (NGO), global consortia, funding agencies, scholarly associations, for-profit organizations, and publishers. These institutions play key roles in training ethnobiologists, funding research and projects, enabling networking and dissemination, setting ethical standards (cf. ISE 2006; SOLAE 2016), and maintaining biocultural collections (Salick et al. 2014). While these institutions enable ethnobiologists' work in many ways, they can also perpetuate issues of access to information and biocultural heritage, hamper ethnobiologists' ability to carry out truly community-engaged research, and disproportionately limit career opportunities for marginalized groups. We believe that ethnobiologists can take concrete steps toward decolonizing institutions of which they are part, either in leadership roles or through advocacy (see Table 2; Supplemental Table S1A; see also Fernández-Llamazares et al. 2021). We recognize that many institutional issues require structural change, but we focus below on areas where ethnobiologists can take critical action that leads towards structural change, drawing on valuable experience from other fields, for example, ecology and conservation (Chaudhury and Colla 2020; Massey et al. 2021; McGill et al. 2021; Tseng et al. 2020).

Advocating for institutional change can be daunting. Recognition of the need for change will be strongly influenced by the attitudes of senior management. Effective change must work at different scales, 
Table 2. Ways in which ethnobiologists can take action toward decolonizing institutions.

\begin{tabular}{|c|c|}
\hline Type of Institution & Actions \\
\hline Educational institutions & - Work to promote the inclusion of different ways of knowing in curricula \\
\hline \multirow[t]{2}{*}{$\begin{array}{l}\text { Universities, museums, } \\
\text { botanical gardens etc. }\end{array}$} & $\begin{array}{l}\text { - Work toward institutional transparency surrounding the relationship } \\
\text { between the institution's history and colonialism }\end{array}$ \\
\hline & $\begin{array}{l}\text { - Reward service to the communities ethnobiologists work with and } \\
\text { research outputs like guidebooks and ecocultural restoration projects }\end{array}$ \\
\hline Natural History Collections & - Encourage repatriation/rematriation of biocultural heritage \\
\hline \multirow[t]{2}{*}{ Academic Societies } & $\begin{array}{l}\text { - Establish more travel awards for participants from Indigenous and Local } \\
\text { Communities (e.g., Abernethy et al. 2020) }\end{array}$ \\
\hline & $\begin{array}{l}\text { - Audit the culture of academic societies and conferences to ensure } \\
\text { inclusivity }\end{array}$ \\
\hline \multirow[t]{2}{*}{ Academic publishing } & - Move toward open access models with minimal (affordable) fees \\
\hline & $\begin{array}{l}\text { - Incentivize articles focused on methods for inclusion, sovereignty, } \\
\text { ecocultural restoration, and other topics }\end{array}$ \\
\hline Funding Agencies & $\begin{array}{l}\text { - When serving on review panels, be cognizant of the time it takes for } \\
\text { relationship building and consultation with communities, and advocate for } \\
\text { alternative "deliverables" }\end{array}$ \\
\hline Conservation organizations & $\begin{array}{l}\text { - Argue for Indigenous Peoples and Local Communities as expert managers } \\
\text { of their environment }\end{array}$ \\
\hline
\end{tabular}

from the individual to the institution and, for many institutions, from the local to national and/or global. Allies must amplify under-represented voices and take on the labor of change. For members of institutions, whether or not with active managerial support, establishing or finding supportive groups to do this work generates solidarity, enables learning from varied lived experiences, and reduces strain on individuals (Chaudhury and Colla 2020).

Systemic change depends on greater representation in institutional membership, crucially including leadership positions (Maas et al. 2021:Figure 4; Massey et al. 2021; Tseng et al. 2020). Ethnobiologists can be active and attentive to diversity and inclusivity while organizing academic meetings and making nominations for awards, editorial boards, panels, and commissioned publications.

\section{Access and Repatriation/Rematriation of Biocultural Heritage}

The centralization of biocultural resources-archives and repositories typically coded by and for Euro-Americans-can be an extractive endeavor which alienates people from their cultural and biological heritage. Failure to acknowledge histories of colonialism and trade, whereby peoples' heritage and intellectual property was taken and displayed in colonial museums in the world's richest countries (Cornish and Nesbitt 2014), has led to the continued marginalization of non-Western forms of knowledge. Repatriation/rematriation of biocultural heritage implies the recognition of the rights of communities to their knowledge and biological resources, from the genetic varieties of the crops they develop to the landscapes they create (Toledo and Alarcón-Cháires 2018). 
Since the international call for repatriation/rematriation of heritage by the United Nations Declaration on the Rights of Indigenous Peoples (UN General Assembly 2007:Article 11), a variety of new forms of repatriation/rematriation have been developed in the museum sector (Anderson and Christen 2019; Coombes and Phillips 2020). Digital access constitutes one part of a more complex conversation about collections that recognizes colonialism is embedded within the infrastructures themselves_-including cataloguing and labeling (Anderson and Hudson 2020). However, many argue that decolonization must, in part, be grounded in the return of physical resources gained through colonization (Tuck and Yang 2012). Ethnobiologists can play an active role in advocating for repatriation/rematriation, as many ethnobiologists are housed at institutions with biocultural collections. In some contexts, this heritage is often overlooked, as in the case of herbaria hosting biocultural heritage in the form of ethnobiological information and voucher specimens (Odonne et al. 2020). To prevent future dispossession of biocultural heritage and erasure of Indigenous Peoples and Local Communities from metadata, ethnobiologists can also advocate for changes to the ways their institutions acquire new information and physical heritage in the first place.

\section{Equity in Access to Literature, Publishing, and Conferences}

Journals, presses, and academic societies are central to the dissemination of ethnobiological research to the larger research community, but access costs and the dominance of English language remain a significant barrier to academics, members of the communities in which ethnobiologists work, and the global public (Clavero 2010; Espin et al. 2017; Mori et al. 2015). The pattern of colonial research is perpetuated when, for example, community members are unable to access the products of the ethnobiological research in which they participated because of paywalls or the language of publication of journal articles. While Open Access journals mitigate this issue to some extent (Lepofsky et al. 2021), they often require expensive article processing charges (in part mitigated by waivers). While ethnobiologists cannot single-handedly change a problematic publishing system, they can challenge its monopolistic nature through choosing to publish in the journals of scholarly societies (e.g., Economic Botany or Journal of Ethnobiology), where profits are invested in the research community, and through 'Platinum' Open Access journals that have no author or reader fees (e.g., Ethnobotany Research and Applications or Ethnoscientia: Revista Brasileira de Etnobiologia e Etnoecologia). It is similarly problematic when members of the communities ethnobiologists work with are unable to attend conferences where their traditional knowledge is being shared. Many academic societies have added travel scholarships for Indigenous Peoples and Local Communities and we support the continuation of this trend.

\section{Realigning Institutional Priorities to Support Community Leadership}

While it is increasingly recognized that ethnobiology research should be truly collaborative with partner communities and that benefits should flow back to those communities (e.g., Gilmore and Eshbaugh 2011), these priorities do not always align with those of host and funding institutions or scientific journals. To move toward decolonizing ethnobiology, ethnobiologists can push to broaden the criteria for research outcomes and accommodate flexibility in project timelines.

Ethnobiology thrives when institutions and their representatives forge genuine relationships with communities, a process which requires trust-building resulting from continuous and extensive consultation, commitments, and dialogue (cf. Adams 
et al. 2014; Christen and Anderson 2019) which can be incompatible with standard durations of research funding. To promote alternatives to extractive data collectionthe "parachute science" discussed further in the section on Decolonizing Projects-we encourage ethnobiologists serving on grant assessment panels to support the extra time and resources necessary for these processes. Similarly, research outputs that may be favored by communities are not always the same as those favored by funders, departmental promotion criteria, or academic journals. We advocate for incentivizing alternative research outputs that are useful to communities, such as guidebooks or ecocultural restoration projects.

\section{Education}

Much has been written on decolonizing education, but ethnobiologists have a unique set of skills and perspectives that could be useful to contribute to this effort. Local and Indigenous knowledge systems have historically been sidelined in many arenas, including education (Chapman and Schott 2020). Ethnobiologists, because of their experience navigating different knowledge systems, are well positioned to encourage their institutions to incorporate different ways of knowing into curricula (Baptista and El-Hani 2009) or help develop new models of education that normalize Indigenous worldviews and teaching methods like those emerging in Latin America (Alvarez-Santullano Busch and Forno Sparosvich 2017; Baldauf 2019; López 2020; Pedota 2011).

\section{Conservation}

While many conservation organizations promote community-based natural resource management, some governments, backed by international NGOs, continue to treat local human-environment interactions as inherently destructive and continue to forcefully remove Indigenous communities from their homelands in the name of protecting biodiversity, in a form of "fortress conservation" (Eichler and Baumeister 2018; Santos Fita et al. 2009). Ethnobiologists and other scholars who bridge social and natural sciences are uniquely positioned to serve as advocates for the conservation benefits of land management by Indigenous Peoples and Local Communities and the role of ethnobotanical research in resolving tensions between nature conservation and human livelihoods, when these arise (Baldauf and de Oliveira Lunardi 2020; Brittain et al. 2020; Kareiva and Marvier 2012; Schaefer et al. 2020).

\section{Revealing Excluded Histories}

Many universities, museums, conservation organizations, and botanical gardens have colonial histories that continue to negatively impact the descendants of displaced communities through past or present extraction of natural resources, labor, and wealth (Brockway 1979; Davis 1995; Drayton 2000; Schiebinger 2009). For example, recently, attention has been drawn to how the United States used Indigenous land misappropriated through deceit, violence, or intimidation to fund land-grant universities (Lee et al. 2020). Ethnobiologists embedded in universities and other institutions are well positioned to spearhead inquiry and dialogue around decolonization due to their ability to communicate across boundaries of disciplines, cultures, and knowledge-systems (Ladio 2017).

\section{Decolonizing Projects}

There exists a long history of research projects causing damage, building mistrust, and disempowering Indigenous Peoples and Local Communities (DeLeeuw et al. 2012; Gaudry 2015; Pierotti and Fogg 2020; Simpson 2004, 2017; Thomas 2015; Wilson 2008). Research projects continue to have outcomes that can be detrimental and re-traumatizing to communities who have survived centuries of colonial oppression and continue to face systemic racism and 
marginalization (Coulthard 2014; Joseph and Turner 2020; Regan 2010; Simpson 2017). When planning and implementing ethnobiology projects, it is essential to understand the historical and contemporary contexts that Indigenous Peoples and Local Communities face as a result of colonization, and the impacts on their knowledge systems and cultural and spiritual traditions (Geniusz 2015; Kimmerer 2013; Simpson 2017). In this section, we explore ways in which researchers can take proactive steps toward decolonizing their research projects (see Table 3; Supplemental Table S1B; see also Fernández-Llamazares et al. 2021) by focusing on three overlapping principles: reciprocity, self-sufficiency and sovereignty, and supporting social justice and self-determination.

\section{Reciprocity}

In addition to ongoing self-reflection about the responsibility of ethnobiologists to the people they work with and benefit from, a researcher must consider tangible actions of resource distribution, training, and other forms of reciprocity ("giving back"; Baker 2016). This relational accountability or Inawendiwin (in Anishinaabemowin), as Nicholas Reo (2019) points out, is an ethical guideline that implies that researchers are responsible for nurturing honorable relationships - that ethnobiologists are committed to community partners regardless of budget and time constraints. Building reciprocal relationships is community specific as there is no "one size fits all" approach.

Western scientists are often caught in the web of doing "parachute science" by visiting and collecting data from field sites in communities and returning to their resident institution to complete the project without contributing to community interests and forging meaningful relationships in the study regions (Barber et al. 2014; Chapman et al. 2015). These practices have strained the relationship between scientists and partners and impeded conservation research in

Table 3. Ways in which ethnobiologists can take action toward decolonizing research projects.

\begin{tabular}{|c|c|}
\hline Stage in project & Actions \\
\hline \multirow[t]{3}{*}{ Planning phase } & $\begin{array}{l}\text { - Learn about the history and politics of land and resource sovereignty } \\
\text { in collaborating communities }\end{array}$ \\
\hline & $\begin{array}{l}\text { - Engage in sufficient consultation with communities to make sure } \\
\text { projects align with local needs and interests }\end{array}$ \\
\hline & $\begin{array}{l}\text { - Consider ways projects can support sovereignty of lands, waters, and } \\
\text { resources in collaborating communities }\end{array}$ \\
\hline \multirow[t]{3}{*}{ During the lifecycle of the project } & $\begin{array}{l}\text { - Find ways to reduce the burden on the community imposed by the } \\
\text { project }\end{array}$ \\
\hline & $\begin{array}{l}\text { - Reimburse community members for their time monetarily or } \\
\text { otherwise }\end{array}$ \\
\hline & - Consider the fieldwork safety of at-risk individuals \\
\hline \multirow[t]{3}{*}{ At the end of the project } & $\begin{array}{l}\text { - Consider alternative/additional project outputs to peer-reviewed } \\
\text { publications if desired by the community }\end{array}$ \\
\hline & $\begin{array}{l}\text { - Ensure that the community has granted permission for any use of } \\
\text { information and media collected. Consider continued co-curation } \\
\text { through a mechanism like biocultural labels }\end{array}$ \\
\hline & $\begin{array}{l}\text { - Continue involvement with the community beyond the end of } \\
\text { funded projects }\end{array}$ \\
\hline
\end{tabular}


the biodiverse countries that need it the most (Barber et al. 2014). Also challenging are large scale comparative projects where it may be difficult to foster genuine connections with communities (Coleman and Von Hellermann 2012).

\section{Self-sufficiency and Sovereignty}

Métis scholar Adam Gaudry (2015) writes about the importance of moving toward research sovereignty in communities where Indigenous Peoples' right to self-determination in relation to research objectives, agendas, methodologies, and uses of data is respected (DeLeeuw et al. 2012). The increasingly rich literature on Indigenous data sovereignty will guide researchers who are seeking to build self-sufficiency without shouldering community partners with unprocessed or inaccessible data. For example, the Native Nations Institute (NNI) of the University of Arizona has collaborated with many Native Nations throughout the U.S. to develop a set of recommendations for researchers to protect Indigenous Peoples' rights to be consulted (Hiraldo et al. 2020) and to retain data sovereignty through various open-source software and web-based platforms (NNI 2021). Indigenous data sovereignty principles should be employed throughout the life of a project-from designing objectives and methodologies to validating research results, disseminating results, storing data, and ensuring access (Kukutai and Taylor 2016; Rainie et al. 2017; Walter et al. 2020).

Advocates for Indigenous data sovereignty center the importance of Indigenous control over data that comes from Indigenous peoples or from Indigenous lands and waters. One practical mechanism that has been developed to address community interests in biodiversity and genetic resources is the Biocultural Labels and Notices (Anderson and Hudson 2020). The Biocultural Labels (for use by Indigenous Peoples and Local Communities) and the accompanying Notices (for use by researchers and institu- tions) are an initiative focused on accurate provenance, transparency, and integrity in research engagements with these communities. The Biocultural Labels are data-markers that help define community expectations and consent about appropriate and future use of research data (Liggins et al. 2021). They provide a practical application of the Nagoya Protocol (Buck and Hamilton 2011) to issues of access and benefit-sharing for genetic resources and support international expectations around the disclosure and origins of community data used in research contexts. For specific examples, see Local Contexts ${ }^{1}, \mathrm{ENRICH}^{2}$, and Stó:Iō Research and Resource Management Centre/Stó:Iō Nation (2016).

Supporting community self-sufficiency in research is a way of enacting reciprocity. This process is not necessarily about training Indigenous Peoples and Local Communities in Western research methods, but rather making space for community-led research that is grounded in their worldviews and driven by community priorities. A shift is required in the way projects are imagined, moving away from pre-designed projects, which too often capture and "refunctionalize" local knowledge to fit outsiders' research agendas (Escobar 1998), toward projects which are designed or co-designed by Indigenous Peoples and Local Communities on their own terms (AIATSIS 2020; Rodrigues et al. 2020). Ethnobiologists can also support self-sufficiency by engaging in in situ biocultural conservation programs in addition to, or instead of, ex-situ conservation, which preserve languages, knowledge, plants, seeds, and history in collections but can lead to separation from local and historical contexts (Braverman 2014). For example, ethnobiologists can promote herbaria, community seed banks, and medicinal plant gardens that are managed by Indigenous communities and have been demonstrated to be effective in conservation and social justice (Dierig et al. 2014; Martin et al. 2016). 


\section{Supporting Social Justice and Self- Determination}

Indigenous Peoples and Local Communities typically have a strong reciprocal relationship with their homelands and the biota therein. We argue that an important way that ethnobiologists can engage in decolonization is through carrying out research that supports traditional sovereignty over these territories and the relationships they encompass (Turner 2020). In 1969, Nehiyaw (Cree) thinker, teacher, and political activist Harold Cardinal wrote about "The Great Swindle," contemplating how Indigenous rights to land and waters were erased by settler nations in a matter of decades. He reflected, "He, the white man, talked one way and wrote another" (Cardinal 1969:33) referring to the empty promises, doublespeak, and outright lies used by colonial-settlers to steal land and waters from Indigenous peoples. Globally, scientists seeking to "decolonize" their research projects might reflect on Cardinal's words, as decolonization at its core should involve the return of lands and waters and their governance to Indigenous peoples (Simpson 2014; Spice 2018; Tuck and Yang 2012). Like Posey and Dutfield (1996) and Hunn (2007), we recognize the responsibility of ethnobiologists in supporting the territorial and resource sovereignty of Indigenous Peoples and Local Communities.

"Action ethnobiology" is a term recently coined to urge our discipline to organize more thoughtfully around land use and land rights among Indigenous Peoples and Local Communities (Armstrong and McAlvay 2019). Ethnobiological research can play an important role in challenging current power inequalities in projects implemented with Indigenous Peoples and Local Communities (Moeller 2018; Wolverton et al. 2014) or involving extractive industries (Spice 2018). Ethnobiologists conducting action-oriented projects include research for, and with, people facing violence on frontlines (Armstrong and Brown 2019), working with
Indigenous Peoples and Local Communities on reclaiming public lands (Fowler 2019), working (critically) with NGOs promoting sovereignty of Indigenous Peoples and Local Communities (Blair 2019), re-structuring research partnerships toward relational accountability-responsibility of researchers to entire communities and the non-human elements of where they work (Reo 2019), and joining with other disciplines like biomonitoring and toxicology to expose health inequalities and environmental racism (Caron-Beaudoin and Armstrong 2019; Golzadeh et al. 2020).

\section{Decolonizing Scholars and Scholarship}

A major step toward decolonization is reflecting on how ethnobiologists, as scholars and as individuals, may be influenced, shaped, and privileged by colonial policies and legacies, and complicit in perpetuating inequity and racism (see Table 4, Supplemental Table 1C). To break down or challenge oppressive legacies and practices that persist in society requires a deeper engagement with the impacts of colonial history on sexism, systemic racism, classism, oppression, academic disciplines, and scholars (Armstrong and Brown 2019; DiAngelo 2018; Regan 2010).

\section{Rejecting Colonial and Derogatory Language}

One step toward decolonizing ethnobiology scholarship is awareness of the language used when writing about work with Indigenous Peoples and Local Communities. In the influential book Pedagogy of the Oppressed, Freire (1970) stated that language is never neutral; it is crucial that ethnobiologists look for ways to avoid diminishing, overgeneralizing, or exoticizing Indigenous peoples and their knowledge systems (Alves and Albuquerque 2010; Duncan 2018; McClatchey 2005). For example, "discovering Indigenous uses" or "lost plants" can imply that knowledge does not exist if it is not published in an 
Table 4. Ways in which ethnobiologists can take action toward decolonizing themselves.

\begin{tabular}{|c|c|}
\hline Category & Actions \\
\hline Language & $\begin{array}{l}\text { - Consciously choose words that do not perpetuate colonial } \\
\text { stereotypes and power dynamics } \\
\text { - Favor words for peoples and places that are preferred by the } \\
\text { peoples living in those places }\end{array}$ \\
\hline $\begin{array}{l}\text { Acknowledging the validity of diverse } \\
\text { knowledge systems }\end{array}$ & $\begin{array}{l}\text { - Avoid using one knowledge system as an objective measure to } \\
\text { evaluate another }\end{array}$ \\
\hline Inclusive citation and authorship & $\begin{array}{l}\text { - Opt for inclusive co-authorship with community members and } \\
\text { others } \\
\text { - Cite diverse international scholars }\end{array}$ \\
\hline Critical Self-reflection and Responsibility & $\begin{array}{l}\text { - Reflect on personal privilege, positionality, and personal biases } \\
\text { - Work to reduce the burden on members of marginalized } \\
\text { communities to educate others on issues surrounding } \\
\text { colonialism and racism }\end{array}$ \\
\hline
\end{tabular}

academic venue, even if it is well-known to the source communities. Likewise, saying that the ethnobiology of a given community or people is "new" or "unknown" similarly implies that knowledge is only valid when documented by outsiders. Authors, reviewers, and editors urgently need to eliminate derogatory terms, such as "uneducated" and "primitive," and in contemporary contexts, "pre-literate" and "pre-industrial," which, when referring to contemporary peoples, implies a trajectory of cultural evolution (Younging 2018). The use of "Old World," "third world," "New World," and "developing world" also carry Eurocentric connotations. Rethinking the relationship of "informant" with the more equitable and respectful "participant," "collaborator," or "local partner" replaces hierarchies with relationships of collaboration and co-production of knowledge (Gilmore and Eshbaugh 2011), but this replacement should reflect an effective change in the way of collaborating, and not just a change of words. The terms that community members use to name and describe themselves in their own language (endonyms) should be set as an ethical standard in writing, rather than exonyms which are often derogatory and inaccurate (for a style guide, see Young- ing 2018). When appropriate, terms that do not downplay the impacts of colonialism (e.g., "unceded territory") should be used. Furthermore, as per the recommendations of the National Aboriginal Health Organization of Canada and the Native American Journalists Association, the term Indigenous Peoples should be capitalized as a sign of respect. In addition, the plural form knowledge systems of Indigenous Peoples and Local Communities should be used to indicate that these are not uniform or monolithic. Finally, we advocate for less jargon-rich discipline-specific language (including acronyms; Wyndham 2017) as it limits the accessibility of research results for the communities and even more so for non-native speakers of the publication language.

Terms for plants, animals, and places should be checked for offensive and racist connotations and community rules should be followed for names that can or cannot be spoken or written in public contexts. Scholars should be inquisitive and reflexive about the existence of racist and xenophobic plant and place names and choose alternative common names that are known for these species and places. For example, some English common names of plants 
have origins in white supremacy and slavery (e.g., dumb cane for Dieffenbachia spp.), or anti-Semitism (e.g., wandering Jew for Tradescantia spp.). Warnings from community members about culturally restricted plant and animal names, imagery, and content need to be clearly placed at the onset of articles and films. The Culturally Sensitive and the Seasonal Traditional Knowledge Labels (mentioned under Projects as a part of the Biocultural Label initiative) are practical mechanisms that can be used by communities to support the recognition of these sensitivities. Bringing community protocols into scholarship, practice, and pedagogy are part of ethnobiological decolonial strategies for change (Walter and Guerzoni 2020).

\section{Acknowledging the Validity of Diverse Knowledge Systems}

Reflecting on how ethnobiologists conceptualize, write, talk, and teach about the relationships between the different knowledge systems is an important step toward decolonization. Training in ethnobiology is often grounded in scientific traditions with a direct origin in the European Age of Enlightenment (Hankins 1985), such as chemistry, pharmacology, and ecologylenses through which ethnobiologists often examine traditional knowledge systems (Vandebroek 2013). While ethnobiology as a field has been at the forefront of documenting diverse worldviews and knowledge systems, in many cases, they are presented in the context of being "validated" by specific dominant scientific lenses. Awareness of language around this issue is also relevant as, for example, "pharmacologically validating Native American knowledge of Taxus brevifolia" conveys a different relationship between the two knowledge systems than "examine pharmacological and Indigenous knowledge about Taxus brevifolia." While ethnobiologists are well situated to facilitate exchange and dialogue between different knowledge systems (Ladio 2017), the use of one knowledge system as the yard- stick to measure the value or accuracy of another perpetuates the dominance of the former. The contexts of comparing knowledge systems vary greatly. For example, while a community might recognize a local landscape as especially diverse, governmental conservation organizations may be more likely to protect the area if that diversity is documented in specific scientific terms (e.g., species richness and evenness). Communicating to other academics and the general public the frequent findings that Indigenous Peoples and Local Communities are often savvy stewards of their environments can be done with scientific analysis but should always respect the integrity of local knowledge.

\section{Inclusive Citation and Authorship}

In addition to writing in respectful and accessible language, it is important to reflect on who are invited as coauthors and whose work is cited as references (Cooke et al. 2021; Marušić et al. 2011), including collaborators from local research institutions (Dahdouh-Guebas et al. 2003). Ethnobiologists also need to consider Indigenous, racial, gender, and youth representation when inviting collaborators (see also Castleden et al. 2010). For example, are community co-authors invited to talk about their own cultures, perspectives, and ways of life (Todd 2016)? Is there gender balance among the authors who ethnobiologists invite as collaborators, and among the authors of papers used when analyzing the social roles of different genders related to ethnobiological knowledge? Finally, scholars can consider positioning themselves as editors and traditional knowledge holders as authors in books to reflect the contributions of community members.

Global science underutilizes publications that are written in languages other than English (Nuñez and Amano 2021; Rau et al. 2017) making invisible not only other languages, but also forms of scientific thinking that might be based in 
worldviews that are at odds with colonial science (Escobar 1998). This can also create significant barriers to prospective authors whose mother tongue is not English, including financial strain to pay for translation and editing (when not provided by journals), reading comprehension difficulties, and anxiety from increased rejection of their papers based on English proficiency (Ramírez-Castañeda 2020). One way ethnobiologists can work to address this issue is to proactively broaden searches for literature and include co-authors familiar with literature in languages other than English. At the same time, ethnobiologists can advocate in English-language journals for the possibility of publishing in other languages. Likewise, English-language publications can be translated to other languages to repatriate/rematriate research results to local collaborators, as practiced already by Ethnobotany Research and Applications. In an attempt to make this article more accessible, we have provided Portuguese and Spanish translations in the supplement.

\section{Critical Self-Reflection and Responsibility}

Colonialism has impacted how cultures relate to race, gender, sexual orientation, class, and other aspects of society and, in many cases, left lasting legacies of discrimination (Bassil 2005; Bourassa et al. 2004). In addition to racial hierarchies, imported forms of sexism, attitudes toward LGBTQ individuals, and class systems persist. These legacies disproportionately impact those who fall under multiple marginalized social categories (e.g., McDowell and Hernández 2010). Ethnobiologists are not exempt from these legacies, and without self-examination, they risk perpetuating them. Understanding how colonial history and racism intersect with ethnobiology can lead ethnobiologists to prepare for encounters with colleagues, institutional leadership, students, family members, or friends who base their understanding of Indigenous and other non-white people on racist foundations (White and Draycott 2020). Though it is often easier to choose silence and comfort, ethnobiologists need to situate themselves against upholding systems of racism where they live and work (DiAngelo 2018).

Ethnobiologists have the responsibility to continuously reflect upon, and identify, their own prejudices. This begins with examining the various cultural factors (identity/race, gender, social class) that affect a person's experience of privilege or discrimination, and how this shapes their belief systems, expectations, and unconscious bias (Gaudry 2015). These reflections can continue with examining the history of one's family, customs, and institution in relation to colonial oppression; for example, on whose Indigenous lands were you raised; where do the plant foods you eat come from; and on whose Indigenous lands does your institution exist? Additional approaches to directly examining implicit bias include engaging in "dialogue to action" exercises (Lyiscott 2019) and writing personal "race stories" (Magee 2019; Tatum 2017:112). Critical examination of one's implicit biases also necessitates confronting the historical realities of injustice. In many places, for example, the historically shaped social construct of race shapes nearly every aspect of life, influencing everything from their physical safety, quality of healthcare, access to education, how much money someone will make, and what their overall life expectancy will be (DiAngelo 2018).

\section{Conclusions}

Colonial legacies and ongoing colonialism continue to influence how ethnobiologists' institutions work, how ethnobiologists carry out research, and how they behave as scholars. Moving beyond the pervasive influence of colonialism and toward a more just and equitable ethnobiology requires sustained engagement. We hope this article will serve as the start of a wider and deeper conversation about decol- 
onizing ethnobiology, which, we suggest, needs to be tackled at three different scales (Figure 1). As part of this conversation, we offer a series of questions to foster reflection (Supplemental Table S1A-C) and a repository of relevant literature for those wanting to engage further (Supplemental Table S2). A great deal more could be written on interwoven issues like classism, gender, sexual orientation, ableism, and intersectionality, and we encourage our colleagues to continue these conversations and develop this work as it relates to ethnobiology.

While we have presented general recommendations for moving toward decolonizing ethnobiology, we also recognize the significant global variability in historical contexts of colonization and cultural contexts of how its legacy persists-and that different types of geographic localities, institutions, research, and applied projects require different approaches. These approaches need to prioritize the particular needs and requirements of each community with whom ethnobiologists seek collaborative partnerships. We acknowledge that our authorship and literature is skewed towards the Anglophone scholarship and extend a call to other scholars worldwide to share their viewpoints, including those that differ radically. We hope to continue learning and re-adjusting our own viewpoints as a result of these collaborations.

\footnotetext{
Notes

${ }^{1}$ www. localcontexts.org.

${ }^{2}$ www.enrich-hub.org
}

\section{Acknowledgments}

We acknowledge the invaluable efforts which this manuscript builds from of many who have worked, and continue to work, to promote social justice, anti-oppression, inclusion, and reciprocity, including members of Lesbian, Gay, Bisexual, Trans, Queer (LGBTQ), Afrodescendant, Latinx, Indigenous, and other communities. We thank the editor and reviewers of this manuscript (Dana Lepofsky, Victoria Reyes-
Garcia, Natasha Lyons, and two anonymous referees) for their detailed and thoughtful reviews.

\section{References Cited}

Abernethy, E. F., I. Arismendi, A. G. Boegehold, C. Colón-Gaud, M. R. Cover, E. I. Larson, E. K. Moody, B. E. Penaluna, A. J. Shogren, A. J. Webster, and M. M. WollerSkar. 2020. Diverse, Equitable, and Inclusive Scientific Societies: Progress and Opportunities in the Society for Freshwater Science. Freshwater Science 39:363-376. DOI:10.1086/709129.

Adams, V., N. J. Burke, and I. Whitmarsh. 2014. Slow Research: Thoughts for a Movement in Global Health. Medical Anthropology 33:179-197. DOI:10.1080/01459740.201 3.858335 .

AIATSIS (Australian Institute of Aboriginal and Torres Strait Islander Studies). 2020. Code of Ethics. AIATSIS, Canberra, Australia. Available from: https://aiatsis.gov.au/research/ ethical-research/code-ethics.

Alvarez-Santullano Busch, M. P., and A. Forno Sparosvich. 2017. Educación Intercultural: Educadoras Mapuches en Escuelas Ajenas: Narrativas en Ocho Poemas. Estudios Pedagógicos (Valdivia) 43:7-26. DOI:10.4067/S0718-07052017000300001.

Alves, A. G. C., and U. P. Albuquerque. 2010. Ethno What? Terminological Problems in Ethnoscience with a Special Emphasis on the Brazilian Context. In Recent Developments and Case Studies in Ethnobotany, edited by U. P. Albuquerque and N. Hanazaki, pp. 67-79. Sociedade Brasileira de Etnobiologia e Etnoecologia, Pernambuco, Brazil.

Anderson, J., and K. Christen. 2019. Decolonizing Attribution: Traditions of Exclusion. Journal of Radical Librarianship 5:113-152. Available at: https://journal.radicallibrarianship.org/index.php/journal/article/ view/38. Accessed on May 1, 2021.

Anderson, J., and M. Hudson. 2020. The Biocultural Labels Initiative: Supporting Indigenous Rights in Data Derived from Genetic Resources. Biodiversity Information Science and Standards 4:e59230. DOI:10.3897/ biss. 4.59230 . 
Armstrong, C. G., and C. Brown. 2019. Frontiers are Frontlines: Ethnobiological Science Against Ongoing Colonialism. Journal of Ethnobiology 39:14-31. https://doi.org/ 10.2993/0278-0771-39.1.14.

Armstrong, C. G., and A. C. McAlvay. 2019. Introduction to Action Ethnobiology. Journal of Ethnobiology 39:3-13. https://doi.org/10. 2993/0278-0771-39.1.3.

Atalay, S. 2012. Community-Based Archaeology: Research With, By, and For Indigenous and Local Communities. University of California Press, Berkeley, CA.

Baker, J. M. 2016. Research as Reciprocity: Northern Cree Community-Based and Community-Engaged Research on Wild Food Contamination in Alberta's Oil Sands Region. Engaged Scholar Journal: Community-Engaged Research, Teaching, and Learning 2:109-123. DOI:10.15402/esj. v2i1.201.

Baker, K., M. P. Eichhorn, and M. Griffiths. 2019. Decolonizing Field Ecology. Biotropica 51:288-292. DOI:10.1111/btp.12663.

Baldauf, C. 2019. From the Colonialist to the "Autobotanical" Approach: The Evolution of the Subject-Object Relationship in Ethnobotanical Research. Acta Botanica Brasilica 33:386-390. DOI:10.1590/0102$33062018 a b b 0343$.

Baldauf, C., and V. de Oliveira Lunardi. 2020. Multiple Perspectives on Biodiversity Conservation: From Concept to Heated Debate. In Participatory Biodiversity Conservation, edited by C. Baldauf, pp. 15-32. Springer, Berlin, Germany. DOI:10.1007/978-3-030-41686-7_2.

Baptista, G. C. S., and C. N. El-Hani. 2009. The Contribution of Ethnobiology to the Construction of a Dialogue Between Ways of Knowing: A Case Study in a Brazilian Public High School. Science \& Education 18:503-520. DOI:10.1007/s11191-0089173-3.

Barber P. H., M. C. A. Ablan-Lagman, A. Ambariyanto, R. G. S. Berlinck, D. Cahyani, E. D. Crandall, R. Ravago-Gotanco, et al. 2014. Advancing Biodiversity Research in Developing Countries: The Need for Changing Paradigms. Bulletin of Marine
Science 90:197-210. DOI:10.5343/bms. 2012.1108.

Bassil, N. N. 2005. The Legacy of Colonial Racism in Africa. Journal of Contemporary Analysis 77:27-40.

Berkes, F. 2012. Sacred Ecology, $3^{\text {rd }}$ edition. Routledge, New York.

Berlin, B. 1992. Ethnobiological Classification. Principles of Categorization of Plants and Animals in Traditional Societies. Princeton University Press, Princeton, NJ.

Blair, J. J. 2019. Splintered Hinterlands: Public Anthropology, Environmental Advocacy, and Indigenous Sovereignty. Journal of Ethnobiology 39:32-49. https://doi.org/10. 2993/0278-0771-39.1.32.

Bourassa, C., K. McKay-McNabb, and M. Hampton. 2004. Racism, Sexism and Colonialism: The Impact on the Health of Aboriginal Women in Canada. Canadian Woman Studies 24:23-30.

Braverman, I. 2014. Conservation Without Nature: The Trouble with In Situ Versus Ex Situ Conservation. Geoforum 51:47-57. DOI:10.1016/j.geoforum.2013.09.018.

Brittain, S., H. Ibbett, E. Lange, L. Dorward, S. Hoyte, A. Marino, E. J. Milner-Gulland, J. Newth, S. Rakotonarivo, D. Veríssimo, and J. Lewis. 2020. Ethical Considerations When Conservation Research Involves People. Conservation Biology 34:925-933. DOI:10.1111/cobi.13464.

Brockway, L. 1979. Science and Colonial Expansion: The Role of the British Royal Botanical Gardens. Academic Press, New York, NY.

Buck M., and C. Hamilton. 2011. The Nagoya Protocol on Access to Genetic Resources and the Fair and Equitable Sharing of Benefits Arising from their Utilization to the Convention on Biological Diversity. Review of European Community \& International Environmental Law 20:47-61. DOI:10.1111/j.1467-9388.2011.00703.x.

Cardinal, H. 1969. The Unjust Society. Hurtig, Edmonton, AB, Canada.

Caron-Beaudoin, É., and C. G. Armstrong. 2019. Biomonitoring and Ethnobiology: Approaches to Fill Gaps in Indigenous Public and Environmental Health. Journal 
of Ethnobiology 39:50-64. https://doi. org/10.2993/0278-0771-39.1.50.

Castleden, H., V. S. Morgan, and A. Neimanis. 2010. Researchers' Perspectives on Collective/Community Co-authorship in Community-Based Participatory Indigenous Research. Journal of Empirical Research on Human Research Ethics 5:23-32. DOI: 10.1525/jer.2010.5.4.23.

Chapman J. M., D. Algera, M. Dick, E. E. Hawkins, M. J. Lawrence, R. J. Lennox, A. M. Rous, et al. 2015. Being Relevant: Practical Guidance for Early Career Researchers Interested in Solving Conservation Problems. Global Ecology and Conservation 4:334-348. DOI:10.1016/j.gecco. 2015.07.013.

Chapman, J. M., and S. Schott. 2020. Knowledge Coevolution: Generating New Understanding Through Bridging and Strengthening Distinct Knowledge Systems and Empowering Local Knowledge Holders. Sustainability Science 15:931-943. DOI:10. 1007/s11625-020-00781-2.

Chaudhury, A., and S. Colla. 2020. Next Steps in Dismantling Discrimination: Lessons from Ecology and Conservation Science. Conservation Letters 14:e12774. DOI:10.1111/ conl.12774.

Christen, K., and J. Anderson. 2019. Toward Slow Archives. Archival Science 19:87116. DOI:10.1007/s10502-019-09307-x.

Clavero, M. 2010. "Awkward Wording. Rephrase": Linguistic Injustice in Ecological Journals. Trends in Ecology and Evolution 25:552-553. DOl:10.1016/j.tree.2010. 07.001 .

Clément, D. 1998. The Historical Foundations of Ethnobiology (1860-1899). Journal of Ethnobiology 18:161-187.

Coleman, S., and P. Von Hellermann, eds. 2012. Multi-sited Ethnography: Problems and Possibilities in the Translocation of Research Methods. Routledge, Oxford, UK.

Conklin, H. C. 1954. The Relation of Hanunó'o Culture to the Plant World. Doctoral Dissertation. Department of Anthropology, Yale University. Available from ProQuest Dissertations \& Theses database (UMI No. 6704119).
Cooke, S. J., V. M. Nguyen, N. Young, A. J. Reid, D. G. Roche, N. J. Bennett, T. Rytwinski, and J. R. Bennet. 2021. Contemporary Authorship Guidelines Fail to Recognize Diverse Contributions in Conservation Science Research. Ecological Solutions and Evidence 2:e12060. DOI:10.1002/26888319.12060 .

Coombes, A. E., and R. B. Phillips, eds. 2020. Museum Transformations: Decolonization and Democratization. Wiley, Hoboken, NJ.

Cornish, C., and M. Nesbitt. 2014. Historical Perspectives on Western Ethnobotanical Collections. In Curating Biocultural Collections: A Handbook, edited by J. Salick, K. Konchar, and M. Nesbitt, pp. 271-293. Royal Botanic Gardens, Kew, Richmond, Surrey, UK.

Coulthard, G. S. 2014. Red Skin White Masks. University of Minnesota Press, Minneapolis.

Dahdouh-Guebas, F., J. Ahimbisibwe, R. Van Mol, and N. Koedam. 2003. Neo-Colonial Science by the Most Industrialised Upon the Least Developed Countries in PeerReviewed Publishing. Scientometrics 56: 329-343. DOI:10.1023/A:1022374703178.

Davis, E. W. 1995. Ethnobotany: An Old Practice, A New Discipline. In Ethnobotany: Evolution of a Discipline, edited by R. E. Schultes and S. Von Reis, pp. 40-51. Dioscorides Press, Portland, OR.

DeLeeuw, S., E. S. Cameron, and M. L. Greenwood. 2012. Participatory and Community-Based Research, Indigenous Geographies, and the Spaces of Friendship: $A$ Critical Engagement. Canadian Geographer/Le Géographe canadien 56:180-194. DOI:10.1111/j.1541-0064.2012.00434.x.

DiAngelo, R. 2018. White Fragility: Why It's So Hard for White People to Talk about Racism. Beacon Press, Boston, MA.

Dierig, D., H. Blackburn, D. Ellis, and M. Nesbitt. 2014. Curating Seeds and Other Genetic Resources for Ethnobiology. In Curating Biocultural Collections: A Handbook, edited by J. Salick, K. Konchar, and M. Nesbitt, pp. 107-125. Royal Botanic Gardens, Kew, Surrey, UK. 
Drayton, R. 2000. Nature's Government: Science, Imperial Britain and the 'Improvement' of the World. Yale University Press, New Haven, CT.

Duncan, S. 2018. The Words We Use and The Worlds We Build. Ethnobiology Letters 9:9-12. DOI:10.14237/ebl.9.1.2018.1045.

Eichler, L., and D. Baumeister. 2018. Hunting for Justice: An Indigenous Critique of the North American Model of Wildlife Conservation. Environment and Society 9:75-90. DOI:10.3167/ares.2018.090106.

Escobar, A. 1998. Whose Knowledge, Whose Nature? Biodiversity, Conservation, and the Political Ecology of Social Movements. Journal of Political Ecology 5:53-82. DOI:10.2458/v5i1.21397.

Espin, J., S. Palmas, F. Carrasco-Rueda, K. Riemer, P. E. Allen, N. Berkebile, K. A. Hecht, et al. 2017. A Persistent Lack of International Representation on Editorial Boards in Environmental Biology. PLOS Biology 15:e2002760. DOI:10.1371/journal.pbio. 2002760.

Fernández-Llamazares, Á., D. Lepofsky, K. Lertzman, C. G. Armstrong, E. S. Brondizio, M. C. Gavin, P. O.'B. Lyver, et al. 2021. Scientists' Warning to Humanity on Threats to Indigenous and Local Knowledge Systems. Journal of Ethnobiology 41:144-169.

Ferrante, J., 2014. Sociology: A Global Perspective. Cengage Learning, Boston, MA.

Fowler, C. S. 2019. Applied Ethnobiology and Advocacy: A Case Study from the Timbisha Shoshone Tribe of Death Valley, California. Journal of Ethnobiology 39:76-89. https:// doi.org/10.2993/0278-0771-39.1.76.

Freire, P. 1970. Pedagogy of the Oppressed. The Continuum International Publishing Group, New York, NY.

Gaudry, A. 2015. Researching the Resurgence: Insurgent Research and CommunityEngaged Methodologies in 21st-Century Academic Inquiry. In Research as Resistance: Revisiting Critical Indigenous and Anti-Oppressive Approaches, edited by L. Brown and S. Strega, pp. 243-263. Canadian Scholars' Press, Toronto, ON, Canada.
Geniusz, M. S. 2015. Plants So Much to Give Us, All We Have to Do Is Ask: Anishinaabe Botanical Teachings. University of Minnesota Press, Minneapolis.

Gilmore, M. P., and W. H. Eshbaugh. 2011. From Researcher to Partner: Ethical Challenges and Issues Facing the Ethnobiological Researcher. In Ethnobiology, edited by E. N. Anderson, D. M. Pearsall, E. S. Hunn, and N. J. Turner, pp. 51-63. Wiley-Blackwell, Hoboken, NJ.

Golan, J., S. Athayde, E. A. Olson, and A. McAlvay. 2019. Intellectual Property Rights and Ethnobiology: An Update on Posey's Call to Action. Journal of Ethnobiology 39:90-109. https://doi.org/10.2993/02780771-39.1.90.

Golzadeh, N., B. Barst, N. Basu, J. Baker, J. Auger, and M. McKinney. 2020. Evaluating the Concentrations of Total Mercury, Methylmercury, Selenium, and Selenium: Mercury Molar Ratios in Traditional Foods of the Bigstone Cree in Alberta, Canada. Chemosphere 250:1-10. DOI:10.1016/j. chemosphere.2020.126285.

Hankins, T. L. 1985. Science and the Enlightenment. Cambridge University Press, Cambridge, UK.

Harrison, F. V., ed. 2010. Decolonizing Anthropology: Moving Further Toward an Anthropology for Liberation, $3^{\text {rd }}$ edition. American Anthropological Association and the Association of Black Anthropologists, Arlington, VA.

Heinrich, M., and P. Bremner. 2006. Ethnobotany and Ethnopharmacy- Their Role for Anti-Cancer Drug Development. Current Drug Targets 7:239-245.

Hiraldo, D., S. R. Carroll, D. M. David-Chavez, M. B. Jäger, and M. Jorgensen. 2020. Native Nation Rebuilding for Tribal Research and Data Governance. NNI Policy Brief Series. Native Nations Institute, University of Arizona, Tucson, AZ.

Horvath, R. J. 1972. A Definition of Colonialism. Current Anthropology 13:45-57.

Hunn, E. 2007. Ethnobiology in Four Phases. Journal of Ethnobiology 27:1-10. https:// doi.org/10.2993/0278-0771(2007)27[1: EIFP]2.0.CO;2. 
ISE (International Society of Ethnobiology). 2006. International Society of Ethnobiology Code of Ethics (with 2008 additions). Available at: http://ethnobiology.net/code-of-ethics/.

Joseph, L., and N. J. Turner. 2020. "The Old Foods Are the New Foods!": Erosion and Revitalization of Indigenous Food Systems in Northwestern North America. Frontiers in Sustainable Food Systems 4:270. DOI:10.3389/fsufs.2020.596237.

Kareiva, P., and M. Marvier. 2012. What is Conservation Science? BioScience 62:962969. DOI:10.1525/bio.2012.62.11.5.

Kendi, I. X. 2017. Stamped from the Beginning: The Definitive History of Racist Ideas in America. Nation Books, New York, NY.

Kimmerer, R. W. 2013. Braiding Sweetgrass: Indigenous Wisdom, Scientific Knowledge and the Teachings of Plants. Milkweed Editions, Minneapolis, MN.

Kukutai, T., and J. Taylor. 2016. Indigenous Data Sovereignty: Toward an Agenda. ANU Press, Canberra, Australia.

Ladio, A. H. 2017. Ethnobiology and Research on Global Environmental Change: What Distinctive Contribution Can We Make? Ethnobiology and Conservation 6:7. DOI:10.15451/ec2017-07-6.7-1-8.

Lee, R., T. Ahtone, M. Pearce, K. Goodluck, G. McGhee, C. Leff, K. Lanpher, and T. Salinas. 2020. Land-Grab Universities: How the United States Funded Land-Grant Universities with Expropriated Indigenous Land [online]. High Country News. Available at: https://www.landgrabu.org/.

Lepofsky, D., C. Heckelsmiller, Á. FernándezLlamazares, and J. Wall. 2021. Seeking a More Ethical Future for Ethnobiology Publishing: A 40-Year Perspective from the Journal of Ethnobiology. Journal of Ethnobiology 41:122-143.

Liggins, L., M. Hudson, and J. Anderson. 2021. Creating Space for Indigenous Perspectives on Access and Benefit-Sharing: Encouraging Researcher Use of the Local Contexts Notices. Molecular Ecology 30:2477-2482. https://doi.org/10.1111/mec.15918.

López, L. E. 2020. What is Educación Intercultural Bilingüe in Latin America Nowadays: Results and Challenges, Journal of Multilin- gual and Multicultural Development. DOI: 10.1080/01434632.2020.1827646.

Lyiscott, J. 2019. Black Appetite. White Food: Issues of Race, Voice, and Justice Within and Beyond the Classroom. Routledge, New York, NY.

Maas, B., R. J. Pakeman, L. Godet, L., Smith, V. Devictor, and R. Primack. 2021. Women and Global South Strikingly Underrepresented Among Top-publishing Ecologists. Conservation Letters e12797. DOI:10.1111/ conl.12797.

Magee, R. V. 2019. The Inner Work of Racial Justice: Healing Ourselves and Transforming our Communities Through Mindfulness. TarcherPerigee, New York, NY.

Maitra, S., and S. Guo. 2019. Theorising Decolonisation in the Context of Lifelong Learning and Transnational Migration: Anti-Colonial and Anti-Racist Perspectives. International Journal of Lifelong Education 38:5-19. DOI:10.1080/02601370.2018.1561533.

Martin, A., B. Coolsaet, E. Corbera, N. M. Dawson, J. A. Fraser, I. Lehman, and I. Rodriguez. 2016. Justice and Conservation: The Need to Incorporate Recognition. Biological Conservation 197:254-261. DOI:10.1016/j.biocon.2016.03.021.

Marušić, A., L. Bošnjak, and A. Jerončić. 2011. A Systematic Review of Research on the Meaning, Ethics and Practices of Authorship across Scholarly Disciplines. PLoS ONE 6:e23477. DOI:10.1371/journal. pone.0023477.

Massey, M. D. B., S. Arif, C. Albury, and V. A. Cluney. 2021. Ecology and Evolutionary Biology Must Elevate BIPOC Scholars. Ecology Letters 24:913-919. DOI:10.1111/ ele.13716.

McClatchey, W. C. 2005. Exorcizing Misleading Terms from Ethnobotany. Ethnobotany Research and Applications 3:1-4.

McDowell, T., and P. Hernández. 2010. Decolonizing Academia: Intersectionality, Participation, and Accountability in Family Therapy and Counseling. Journal of Feminist Family Therapy 22:93-111.

McGill, B. M., M. J. Foster, A. N. Pruitt, S. G. Thomas, E. R. Arsenault, J. Hanschu, K. Wahwahsuck, E. Cortez, K. Zarek, T. D. 
Loecke, and A. J. Burgin. 2021. You Are Welcome Here: A Practical Guide to Diversity, Equity, and Inclusion for Undergraduates Embarking on an Ecological Research Experience. Ecology and Evolution 11: 3636-3645. DOI:10.1002/ece3.7321.

Moeller, N. I. 2018. Plants That Speak and Institutions That Don't Listen: Notes on the Protection of Traditional Knowledge. In Food Sovereignty, Agroecology and Biocultural Diversity: Constructing and Contesting Knowledge, edited by M. Pimbert, pp. 202233. Routledge, London, UK.

Mori, A. S., S. Qian, and S. Tatsumi. 2015. Academic Inequality through the Lens of Community Ecology: A Meta-Analysis. Peer) 3:e1457. DOI:10.7717/peerj.1457.

Nabhan, G. P., F. Wyndham, and D. Lepofsky. 2011. Ethnobiology for a Diverse World Ethnobiology Emerging from a Time of Crisis. Journal of Ethnobiology 31:172175. https://doi.org/10.2993/0278-077131.2.172.

NNI (Native Nations Institute). 2021. Native Nations Institute, University of Arizona. Indigenous Governance Database [web page]. URL: https://nnigovernance.arizona. edu. Accessed on May 1, 2021.

Nuñez, M. A., and T. Amano. 2021. Monolingual Searches Can Limit and Bias Results in Global Literature Reviews. Nature Ecology \& Evolution 5:264. DOI:10.1038/s41559020-01369-w.

Odonne, G., M. Tareau, and T. van Andel. 2020. Geopolitics of Bitterness: Deciphering the History and Cultural Biogeography of Quassia amara L. Journal of Ethnopharmacology 113546. DOI:10.1016/j.jep. 2020.113546.

Pedota, L. 2011. Indigenous Intercultural Universities in Latin America: Interpreting Interculturalism in Mexico and Bolivia. Master's Thesis, Loyola University, School of Education, Chicago. Available at: https:// ecommons.luc.edu/cgi/viewcontent.cgi?article $=1515 \&$ context $=$ luc_theses. Accessed on Jan 6, 2021.

Pierotti, R., and B. R. Fogg. 2020. Neocolonial Thinking and Respect for Nature: Do Indigenous People have Different Relationships with Wildlife than Europeans? Ethnobi- ology Letters 11:48-57. DOI:10.14237/ebl. 11.1.2020.1674.

Posey, D. A. 1990. Intellectual Property Rights: What is the Position of Ethnobiology? Journal of Ethnobiology 10:93-98.

Posey, D. A., and G. Dutfield. 1996. Beyond Intellectual Property: Toward Traditional Resource Rights for Indigenous Peoples and Local Communities. International Development Research Centre (IDRC), Ottawa, Canada.

Radcliffe, S. A. 2017. Decolonising Geographical Knowledges. Transactions of the Institute of British Geographers 42:329-333. DOI:10.1111/tran.12195.

Rahaman, S., R. Yeazdani, and R. Mahmud. 2017. The Untold History of Neocolonialism in Africa (1960-2011). History Research 5:9-16. DOI:10.11648/j.history. 20170501.12.

Rainie, S. C., J. L. Schultz, E. Briggs, P. Riggs, and N. L. Palmanteer-Holder. 2017. Data as a Strategic Resource: Self-Determination, Governance, and the Data Challenge for Indigenous Nations in the United States. International Indigenous Policy Journal 8:1. DOI:10.18584/iipj.2017.8.2.1.

Ramírez-Castañeda, V. 2020. Disadvantages in Preparing and Publishing Scientific Papers Caused by the Dominance of the English Language in Science: The Case of Colombian Researchers in Biological Sciences. PLOS ONE 15:e0238372. DOI:10.1371/ journal.pone.0238372.

Rau, J. R., A. Monjeau, J. C. Pizarro, and C. B. Anderson. 2017. Cuanto Más Publicamos, Menos Nos Citan. Ecología Austral 27:385391. DOI:10.25260/EA.17.27.3.0.453.

Regan, P. 2010. Unsettling the Settler Within. UBC Press, Vancouver, BC, Canada.

Reo, N. J. 2019. Inawendiwin and Relational Accountability in Anishnaabeg Studies: The Crux of the Biscuit. Journal of Ethnobiology 39:65-75. https://doi.org/10.2993/02780771-39.1.65,

Reyes-García, V., D. García-del-Amo, P. Benyei, Á. Fernández-Llamazares, K. Gravani, A. B. Junqueira, V. Labeyrie, X. Li, D. M. Matias, A. McAlvay, and P. G. Mortyn. 2019. A Collaborative Approach to Bring Insights 
from Local Observations of Climate Change Impacts into Global Climate Change Research. Current Opinion in Environmental Sustainability 39:1-8. DOI:10.1016/j.cosust. 2019.04.007.

Rodrigues, E., F. Cassas, B. E. Conde, C. Da Cruz, E. H. P. Barretto, G. Dos Santos, G. M. Figueira, et al. 2020. Participatory Ethnobotany and Conservation: A Methodological Case Study Conducted with Quilombola Communities in Brazil's Atlantic Forest. Journal of Ethnobiology and Ethnomedicine 16:1-12.

Salick, J., K. Konchar, and M. Nesbitt, eds. 2014. Curating Biocultural Collections: A Handbook. Royal Botanic Gardens, Kew, Surrey, UK.

Salick, J., Z. Fang, and A. Byg. 2009. Eastern Himalayan Alpine Plant Ecology, Tibetan Ethnobotany, and Climate Change. Global Environmental Change 19:147-155. DOI: 10.1016/j.gloenvcha.2009.01.008.

Santos-Fita, D., E. Naranjo Piñera, and R. Mariaca Méndez. 2009. Hacia un Etnoconservacionismo de la Fauna Silvestre. In Manual de Etnozoología, edited by E. M. Costa Neto, D. Santos Fita, and M. VargasClavijo, pp. 96-118. Tundra Ediciones, Almenara, Castellón, Spain.

Schaefer, J., K. Magellan, R. Sluka, S. Kolipaka, O. Gonzalez, A. A. M. Razali, G. R. Clements, and C. Elkin. 2020. The Efficacy of Using SCB Guidelines to Facilitate Conservation Science-Faith Collaboration: Experiences in the Field. Frontiers in Environmental Science 8:558956. DOI:10.3389/ fenvs.2020.558956.

Schiebinger, L. 2009. Plants and Empire. Harvard University Press, Cambridge, MA.

Shoemaker, N. 2015. A Typology of Colonialism. Perspectives on History 53:29-30.

Simpson, L. B. 2004. Anticolonial Strategies for the Recovery and Maintenance of Indigenous Knowledge. American Indian Quarterly 28:373-384.

Simpson, L. B. 2014. Land as Pedagogy: Nishnaabeg Intelligence and Rebellious Transformation. Decolonization: Indigeneity, Education \& Society 3:1-25. Available at: https://jps.library.utoronto.ca/index.php/ des/article/view/22170. Accessed on May 1, 2021.

Simpson, L. B. 2017. As We Have Always Done: Indigenous Freedom Through Radical Resistance. University of Minnesota Press, Minneapolis.

Smith, L. T. 2012. Decolonizing Methodologies. Palgrave Macmillan, New York, NY.

SOLAE (Sociedad Latinoamericana de Etnobiología). 2016. Código de Ética. Etnobiologia 14 (Suppl. 1). Available at: https://asociacionetnobiologica.org.mx/aem/codigo-de-etica-de-solae. Accessed on May 1, 2021.

Spice, A. 2018. Fighting Invasive Infrastructures: Indigenous Relations against Pipelines. Environment and Society 9:40-56. DOI:10.3167/ares.2018.090104.

Stó:Iō Research and Resource Management Centre/Stó:Iō Nation. 2016. Stámés Sxwōxwiyám Sqwélqwel [web page]. http:// digitalsqewlets.ca/traditional-knowledge_ connaissances_traditionnelles-eng.php.

Tatum, B. D. 2017. Why are All the Black Kids Sitting Together in The Cafeteria? and Other Conversations About Race, $2^{\text {nd }}$ edition. Hachette Book Group, New York, NY.

Thomas, R. Q. 2015. Honoring the Oral Traditions of the Tat Mustimuxw (Ancestors) Through Storytelling. In Research as Resistance: Revisiting Critical, Indigenous, and Anti-Oppressive Approaches, edited by L. Brown and S. Strega, pp. 177-198. Canadian Scholars' Press, Toronto, ON, Canada.

Todd, Z. 2016. An Indigenous Feminist's Take on the Ontological Turn: 'Ontology' is Just Another Word for Colonialism. Journal of Historical Sociology 29:4-22. DOI:10.1111/johs.12124.

Toledo, V., and P. Alarcón-Cháires. 2018. Tópicos bioculturales. Reflexiones sobre el concepto de bioculturalidad y la defensa del patrimonio biocultural de México. Universidad Autónoma de México, Mexico City.

Tseng, M., R. W. El-Sabaawi, M. B. Kantar, J. H. Pantel, D. S. Srivastava, and J. L. Ware. 2020. Strategies and Support for Black, Indigenous, and People of Colour in Ecology and Evolutionary Biology. Nature Ecology \& Evolution 4:1288-1290. DOI:10.1038/ s41559-020-1252-0. 
Tuck, E., and K. W. Yang. 2012. Decolonization is not a Metaphor. Decolonization: Indigeneity, Education \& Society 1:1-40. DOI:10.1093/ acprof:oso/9780199253487.003.0014.

Turner, N. J. ed., 2020. Plants, People, and Places: The Roles of Ethnobotany and Ethnoecology in Indigenous Peoples' Land Rights in Canada and Beyond (Vol. 96). McGill-Queen's Press-MQUP, Montreal, QC, Canada.

UN General Assembly. 2007. United Nations Declaration on the Rights of Indigenous Peoples. A/RES/61/295. Available at: https:// www.refworld.org/docid/471355a82.html. Accessed on February 12, 2021.

Vandebroek, I. 2013. Intercultural Health and Ethnobotany: How to Improve Healthcare for Underserved and Minority Communities? Journal of Ethnopharmacology 148:746754. DOI:10.1016/j.jep.2013.05.039.

Walter, M., and M. Guerzoni. 2020. How a University Can Embed Indigenous Knowledge in a Curriculum and Why it Matters. The Conversation. October 15, 2020. Available at: https://theconversation.com/how-a-university-can-embed-indigenous-knowledgeinto-the-curriculum-and-why-it-matters147456. Accessed on February 6, 2021.

Walter, M., T. Kukutai, S. Carroll, and D. Rodriguez-Lonebear, eds. 2020. Indigenous Data Sovereignty and Policy. Routledge, New York, NY.
White, W. A., and C. Draycott. 2020. Why the Whiteness of Archaeology is a Problem. Sapiens. October 7, 2020. Available at: https://www.sapiens.org/archaeology/ archaeology-diversity/. Accessed on January 25, 2020.

Wilson, S. 2008. Research is Ceremony: Indigenous Research Methods. Fernwood Publishing, Winnipeg, MB, Canada.

Wolverton, S. 2013. Ethnobiology 5: Interdisciplinarity in an Era of Rapid Environmental Change. Ethnobiology Letters 4:21-25. DOI:10.14237/ebl.4.2013.11.

Wolverton, S., J. M. Nolan, and W. Ahmed. 2014. Ethnobiology, Political Ecology, and Conservation. Journal of Ethnobiology 34:125-152. https://doi.org/10.2993/02780771-34.2.125.

Wyndham, F. S. 2017. The Trouble with TEK. Ethnobiology Letters 8:78-80. DOI:10.14237/ ebl.8.1.2017.1006.

Wyndham, F. S., D. Lepofsky, and S. Tiffany. 2011. Taking Stock in Ethnobiology: Where Do We Come From? What Are We? Where Are We Going? Journal of Ethnobiology 31:110-127. https://doi.org/10.2993/02780771-31.1.110.

Younging, G., 2018. Elements of Indigenous Style: A Guide for Writing by and about Indigenous Peoples. Brush Education, Edmonton, $\mathrm{AB}$, Canada. 